\title{
Optimization of the operating parameters of electrocoagulation using aluminum electrode and application to the Dam waters of Sidi Said Ben Mâachou
}

\author{
Laabi Anass ${ }^{1,2}$, Lekhlif Brahim ${ }^{1,2}$, Abdellah Anouar Elfoulani ${ }^{2,3}$ and El hassan Mallil ${ }^{1}$ \\ ${ }^{1}$ Higher National School of Electricity and Mechanics, University Hassan-II, El Jadida Road, B.P 8108, Oasis, \\ Casablanca, Morocco \\ ${ }^{2}$ Water Treatment and Climate Change, Environment Engineering Laboratory, Hassania School \\ of Public Works, Km 7, El Jadida Road, B.P 8108, Oasis, Casablanca, Morocco \\ ${ }^{3}$ Laboratory of Organic Synthesis, Extraction and Valorization, Faculty of Sciences Ain Chock, University \\ Hassan-II, Km8 El Jadida Road, B.P 5366 Maarif Casablanca 20100, Morocco
}

\begin{abstract}
The objective of this work was to optimize electrocoagulation treatment parameters for the removal of colloidal suspension in dam water, reducing the cost and improving the quality of the treatment. For this purpose, we studied the impact of optimizing the volume of treated water and the agitation speed on the efficiency of electrocoagulation treatment of synthetic water simulating surface water. After the optimization of these parameters, we proceeded to apply it on the waters of the Sidi Said Ben Mâachou dam. The electrocoagulation test was realized in a batch reactor with two flat, parallel aluminum electrodes powered by a direct voltage of $12 \mathrm{~V}$ DC voltage. The ions released by electrolysis are stirred using a mechanical stirrer with flat blades. Performance monitoring was carried out using the following parameters: $\mathrm{pH}$, conductivity, turbidity. The analysis of the various monitoring parameters showed that the performance of electrocoagulation is affected by the factors studied. The results obtained showed that intensive agitation of the solution leads to the destruction of the flocs, which subsequently minimizes the efficiency of the treatment.
\end{abstract}

Keywords: electrocoagulation, electrodes, treatment, surface water, turbidity, stirring speed.

\section{Introduction}

The surface water is affected by many factors, mainly the organic matter and suspended matter. They make it difficult to treat them ${ }^{1}$. Which sometimes requires the use of more or less elaborate treatment regimens to eliminate undesirable elements effectively ${ }^{2,3}$. Indeed, the removal of these elements requires the use of a number of techniques, such as membrane filter technology, electrocoagulation, sonochemical methods, electrochemical oxidation, photocatalytic oxidation, adsorption on activated carbon and enhanced coagulation ${ }^{4}$. However, electrocoagulation has great benefits due to the cost and duration of the process, and the energy dissipated during the treatment, including coagulation, which involves the use of cations, that reduces the negative potential (Potential zeta $\zeta$ ) created by the double-layer surrounding the colloidal particles ${ }^{5}$.

Electrocoagulation, derived from conventional coagulation, is increasingly used in water treatment,

Corresponding author: Anass Laabi

Email address: laabianass@yahoo.fr

DOI: http://dx.doi.org/10.13171/mjc10402004241251al including the removal of suspended and natural organic matter (NOM) from surface waters ${ }^{6-8}$. It is based on the principle of coagulation by cations released under the action of a direct electrical voltage between two opposite metal plates made of iron or aluminum ${ }^{9,10}$ Figure 1. Often electrocoagulation is associated with electroflotation (ECF), due to the action of gas bubbles released at the electrodes ${ }^{11,12}$ Figure 1.

Three stages of electrocoagulation technology implicate in the purification of wastewater are as: (1) electrolytic oxidation of sample water to generate coagulants; (2) pollutant destabilization, emulsion, deterioration and particle suspension; (3) agglomeration of resultant particles to generate flocs: comprised of colloids entrapped sludge blanket formed from coagulation reaction. These flocs are similar to chemical flocs and are larger acidresistant, bounded less water and stable, that's why can be easily separated out by rapid sand filtration ${ }^{13}$. The electrocoagulation process is economical as it produces relatively less amount of 
sludge in comparison with conventional processes. Often electrocoagulation is associated with electroflotation ${ }^{11,12}$ Figure 1, the electrochemical reactions take place at anode and cathode as discussed in equations 1-5. During electrocoagulation, $\mathrm{H}_{2}$ is evolved at cathode in the form of bubbles, that discards particles by flotation known as electroflotation ${ }^{14}$

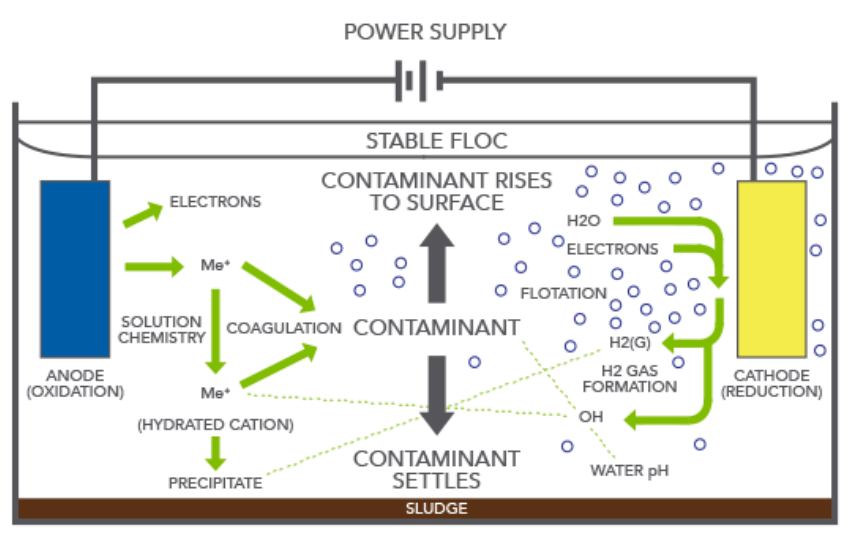

Figure 1. electrocoagulation setup

The main reactions that occur at the electrodes (in the case of aluminum electrodes) are ${ }^{15}$ :

- At the anode:

The oxidation of the metal:

$\mathrm{Al} \rightarrow \mathrm{Al}^{3+}+3 \mathrm{e}^{-}$

This reaction can be accompanied by the formation For high $\mathrm{pH}$ values, the cathode can be attacked by $\mathrm{OH}^{-}$ions according to the following reaction:

$$
2 \mathrm{Al}(\mathrm{s})+6 \mathrm{H}_{2} \mathrm{O}(\mathrm{l})+2 \mathrm{OH}^{-}(\mathrm{aq}) \rightarrow 2\left[\mathrm{Al}(\mathrm{OH})_{4}\right]^{-}(\mathrm{aq})+3 \mathrm{H}_{2}(\mathrm{~g})
$$

In an acidic medium, $\mathrm{Al}^{3+}$ hydrolyzes to give rise to hydrolyzed monomeric and polymer complexes ${ }^{16}$, such as $\mathrm{Al}(\mathrm{OH})_{2}{ }^{+}, \mathrm{Al}(\mathrm{OH})^{2+}, \mathrm{Al}(\mathrm{OH})_{4}^{-}, \mathrm{Al}_{6}(\mathrm{OH})_{15^{3+}}$, $\mathrm{Al}_{7}(\mathrm{OH})_{17^{4+}}, \quad \mathrm{Al}_{8}(\mathrm{OH})_{20}{ }^{4+}, \quad \mathrm{Al}_{13} \mathrm{O}_{4}(\mathrm{OH})_{24}{ }^{7+}$, $\mathrm{Al}_{13}(\mathrm{OH})_{34}{ }^{5+}$. These entities neutralize, with their positive charges, (zeta potential). When the $\mathrm{pH} \geq 4$ hydrolyzed complex of polynuclear structure ${ }^{17} \mathrm{Al}_{13} \mathrm{O}_{4}(\mathrm{OH})^{247+}$, gives by precipitation $\mathrm{Al}(\mathrm{OH})_{3}$ Reaction 5 .

$\mathrm{Al}^{3+}(\mathrm{aq})+3 \mathrm{OH}^{-} \rightarrow \mathrm{Al}(\mathrm{OH})_{3}$ precipitated

$\mathrm{Al}(\mathrm{OH})_{3}$, as well as other polymers that may form in the $\mathrm{pH}$ range between ${ }^{18} 4$ and 9 , can contribute to of oxygen by electrolysis of water at high current densities:

$$
2 \mathrm{H}_{2} \mathrm{O}(\mathrm{l}) \rightarrow 4 \mathrm{H}^{+}(\mathrm{aq})+\mathrm{O}_{2}(\mathrm{~g})+4 \mathrm{e}^{-}
$$

- At the cathode:

The reduction of water:

$\mathrm{H}_{2} \mathrm{O}+\mathrm{e}^{-} \rightarrow 1 / 2 \mathrm{H}_{2}+\mathrm{OH}^{-}$

the adsorption removal of soluble organic compounds and suspended matter.

\section{Materials and Methods}

\subsection{Synthetic Solutions}

In the first part, the tests were realized on synthetic solutions prepared in the laboratory from distilled water and clay to obtain a water similar to surface water. The clay-water mixture is left to settle for a few minutes, and then the supernatant undergoes several adjustments to get a synthetic solution with the desired turbidity.

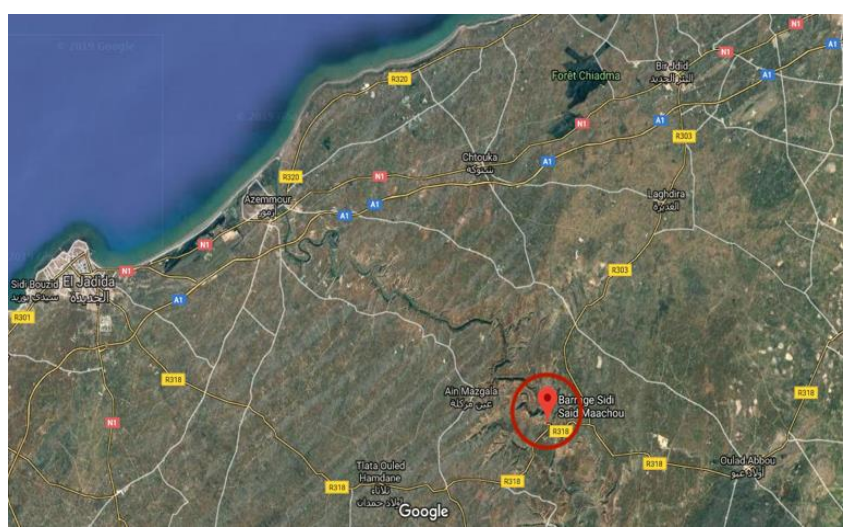

Figure 2. Dam location and water withdrawal 
In the second part, the optimized parameter tests were made on dam waters of Sidi Said Ben Mâachou located on the Oum Er Rbia river Figure 2. This dam is one of the main sources that feed the south of Greater Casablanca.

\subsection{Tests Realised}

In this work, we studied the effect of these parameters (stirring rate, power/volume of the synthetic solution) on the efficiency of electrocoagulation treatment. So, we proceeded with the tests based on agitation with two speed $20 \mathrm{rpm}$ and $60 \mathrm{rpm}$ in a synthetic solution of 1 liter. Then, the same tests were carried out on a 5-liter synthetic solution. Finally, tests were achieved with two blades of different surfaces.

Electrocoagulation tests were also carried out on real water from the Sidi Said Ben Mâachou dam, using the optimized parameters in the previous tests.

\subsection{Parameters and Measurement Methods}

After every ten minutes of electrocoagulation treatment, a $20 \mathrm{~mL}$ sample is taken and allowed to settle for 15 minutes. The parameters measured are turbidity, $\mathrm{pH}$, conductivity, and temperature. Turbidity is measured using a Palintest
7000 photometer turbidimeter. The $\mathrm{pH}$ is measured using a HACH pH meter of type HQ40D, whose probe also measures the temperature. The conductivity is measured by an Orion model 125 conductivity meter. A DRX analysis was performed using a Bruker D8 Advance diffractometer to identify the structure of the sludge and soil.

\subsection{Electrocoagulation Materials}

Electrocoagulation was performed as shown in Figure 1.2 parallel flat electrodes $(14,5 \mathrm{~cm} * 2 \mathrm{~cm}$ $* 0,2 \mathrm{~cm})$ wide with an inter-electrode distance of $3 \mathrm{~cm}$, dipping to a depth of $6 \mathrm{~cm}$ into a cylindrical glass beaker ( 1 liter and 5 liters). They are made of aluminum and powered by a DC electric generator with variable potential (0 to 30 Volts), model AL 823 working under a voltage of $220 \mathrm{~V}$ and having a power of $550 \mathrm{~W}$. The direct voltage applied to both electrodes is $12 \mathrm{~V}$. A mechanical paddle stirrer is immersed in the solution to be treated. The blades are located below the lower ends of the electrodes to maintain the mixing of the formed aggregates Figure 3.

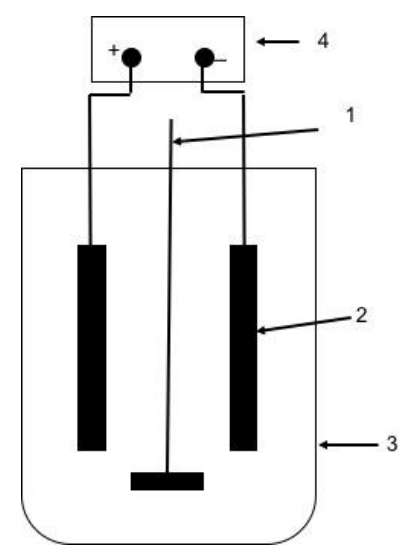

Figure 3. Experimental set-up of the electrocoagulation

(1) mechanical agitator (2) aluminum electrodes (3) electrocoagulation cell (4) DC generator
The following Table 1 gives the characteristics of the agitator :

Table 1. Agitator characteristics.

\begin{tabular}{|c|c|}
\hline & Agitator \\
\hline Form & flat blades \\
\hline $\mathbf{N}_{\mathbf{p}}$ & 2 \\
\hline $\mathbf{D}_{\mathbf{p}}(\mathbf{c m})$ & 7,28 \\
\hline $\mathbf{L}_{\mathbf{p}}(\mathbf{c m})$ & 2 \\
\hline $\mathbf{S}_{\mathbf{p}} / \mathbf{V}_{\mathbf{r}}\left(\mathbf{m}^{\mathbf{2}} / \mathbf{m}^{\mathbf{3}}\right)$ & 1,4 \\
\hline $\mathbf{D}_{\mathbf{p}} / \mathbf{D}_{\mathbf{r}}$ & 0,693 \\
\hline
\end{tabular}

Np: number of blades, Dp: blade diameter, Lp: blade width, Sp: blade surface, Dr: reactor diameter, Vr: reactor volume.

It should be noted that the gas bubbles of hydrogen and oxygen released at the cathode and anode respectively also contribute to the agitation of the solution.

The characteristics of the prepared synthetic solution are as follows Table 2: 
Table 2. Characteristics of the synthetic solution.

\begin{tabular}{|c|c|c|}
\hline $\mathbf{p H}$ & Conductivity $(\boldsymbol{\mu S} / \mathbf{c m})$ & Turbidity (NTU) \\
\hline $\mathbf{7 , 3}$ & 660 & 110 \\
\hline
\end{tabular}

The characteristics of the Sidi Said Ben Mâachou

dam waters are given in the following Table 3:

Table 3. Dam water characteristics.

\begin{tabular}{|c|c|c|}
\hline $\mathbf{p H}$ & Conductivity $(\mathbf{m S} / \mathbf{c m})$ & Turbidity (NTU) \\
\hline $\mathbf{7 , 8 5}$ & 2,92 & 100 \\
\hline
\end{tabular}

Treatment efficiency was assessed by the turbidity abatement rate. This allowance rate is determined according to the following formula:

$\%$ abatement $(X)=\frac{\mathrm{Ci}(\mathrm{X})-\mathrm{Cf}(\mathrm{X})}{\mathrm{Ci}(\mathrm{X})} \times 100$

With Ci: initial turbidity of the synthetic solution and Cf: final turbidity of $\mathrm{X}$.

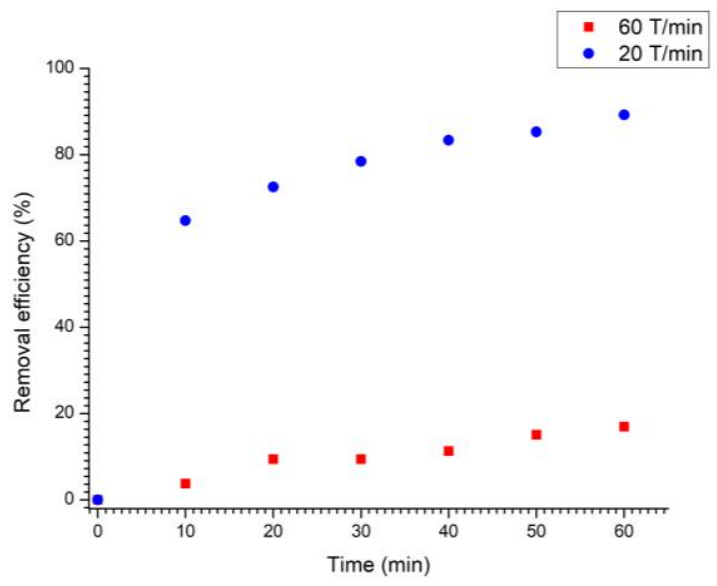

\section{Results and discussion}

\subsection{Synthetic waters}

\subsubsection{Effect of stirring speed}

Electrocoagulation tests performed at two different speeds of $20 \mathrm{rpm}$ and $60 \mathrm{rpm}$ on a volume of 1 liter gave the turbidity results presented in the following Figures 4:

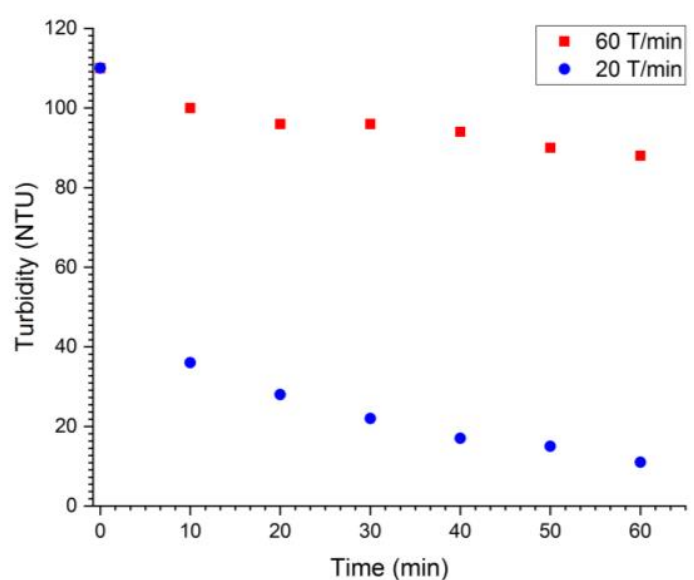

Figure 4. Turbidity abatement and performance as a function of time

For the test performed at $20 \mathrm{rpm}$, the turbidity removal reaches a $90 \%$ reduction rate after 60 minutes. For the $60 \mathrm{rpm}$ speed, this rate is only at $17 \%$. These results highlight the effect of agitation on the removal of suspended matter. Indeed, to ensure good coagulation, it is necessary to provide sufficient agitation energy to destabilize the suspended matter and aggregate it ${ }^{19,20}$.

However, when the agitation is too intense, it can break up the aggregated particles. This is probably the case for the test at $60 \mathrm{rpm}$. The energy supplied per unit volume is higher than for the test at $20 \mathrm{rpm}$.

Some authors have done similar work. showed that cadmium removal was achieved very fast at a moderate stirring rate of $300 \mathrm{rpm}-1$. They proved that the adsorption of $\mathrm{Cd}$ (II) ions by the coagulating aluminum hydroxide $\mathrm{AlOH}_{3}$ occurred very effectively at stirring rates of 300 and $450 \mathrm{rpm}-1$ compared to $600 \mathrm{rpm}-1$ where there was a slight decrease in treatment efficiency which explained this by the fact that excessive stirring causes a rupture to the flocs ${ }^{21}$.

\subsubsection{Effect of $\mathbf{p H}$}

It seems that $\mathrm{pH}$ has an important role in the tests performed, as shown by some authors ${ }^{22}$. Looking at the $\mathrm{pH}$ evolution Figure 5, we see that it increases rapidly and then stabilizes. During this first phase, when the increase can be attributed to hydroxide ions $\left(\mathrm{OH}^{-}\right)$due to water reduction reaction 3 , the suspended matter is removed by electrostatic coagulation. Over time, the $\mathrm{pH}$ stabilizes following the formation of $\mathrm{Al}(\mathrm{OH})_{3}$ reaction 5 or other solids, as suggested by some authors ${ }^{23,18}$, coagulation of suspended matter, in this case, is done by adsorption on the solids thus formed ${ }^{24}$. 


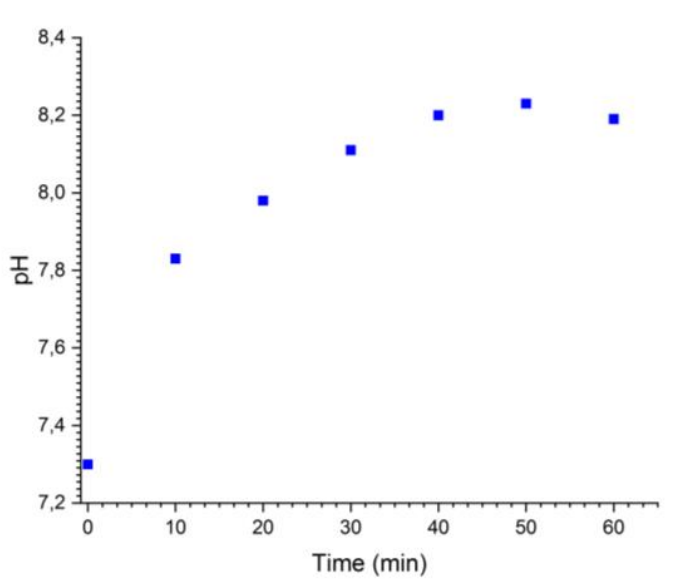

Figure 5. Evolution of $\mathrm{pH}$ as a function of time for stirring speed $20 \mathrm{rpm}$

\subsubsection{Effect of conductivity}

Examination of the conductivity evolution Figure 6 shows an increase, probably due to the release of $\mathrm{Al}^{3+}$ and $\mathrm{OH}-$ ions reactions 1,2 , and $3{ }^{25}$. From 40 minutes of electrocoagulation, a decrease in conductivity is observed, which can be explained by

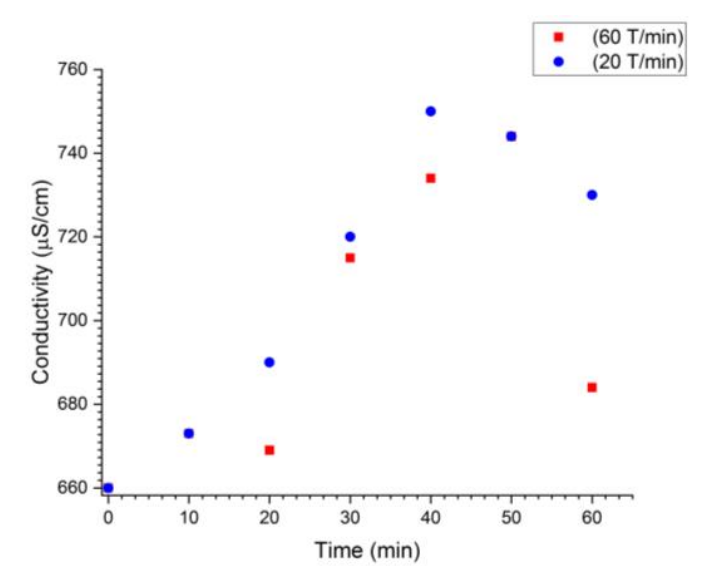

Figure 6. Evolution of conductivity as a function of time

the adsorption of minerals on $\mathrm{Al}(\mathrm{OH})_{3}$ particles and other solids that can form when the $\mathrm{pH}$ increases, as mentioned above, or by bridging the leaves of clay particles ${ }^{1,26}$ from metal bridges with $\mathrm{Al}^{3+}$.

The tests performed at $60 \mathrm{rpm}$ for 1-liter and 5-liter volumes gave the results shown in Figure 7.

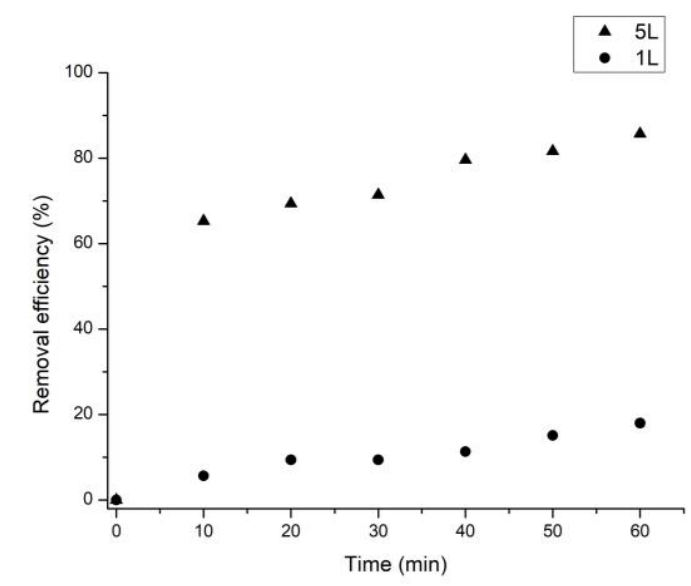

Figure 7. Evolution of turbidity as a function of time for the test at $60 \mathrm{rpm}$

These results confirm the effect observed in previous tests on specific power. The power dissipated in 1 liter being too high, not allowing good coagulation. This same power dissipated in 5 liters makes coagulation possible. It is improving, the abatement rate reaches $85.71 \%$ compared to $17 \%$ obtained for a stirring speed of $60 \mathrm{rpm}$ for 1 liter.
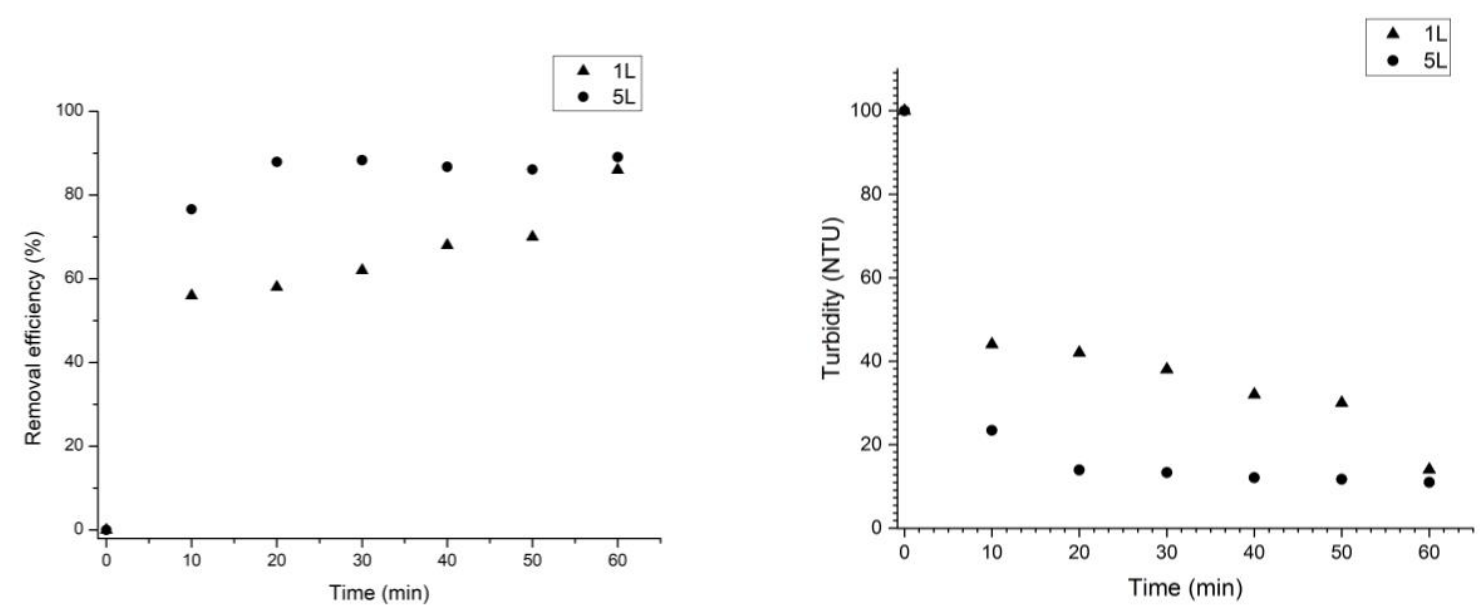

Figure 8. Turbidity abatement and performance as a function of time 


\subsection{Dam waters}

The electrocoagulation tests on the dam water, performed at a stirring rate of $20 \mathrm{rpm}$, gave the results shown in Figure 8.

It can be observed that electrocoagulation performed at a speed of $20 \mathrm{~T} / \mathrm{min}$ in a volume of 5 liters makes it possible to achieve a reduction rate of $89 \%$ after 20 minutes. For a volume of 1 liter, the turbidity reduction reaches $86 \%$, but after 60 minutes.

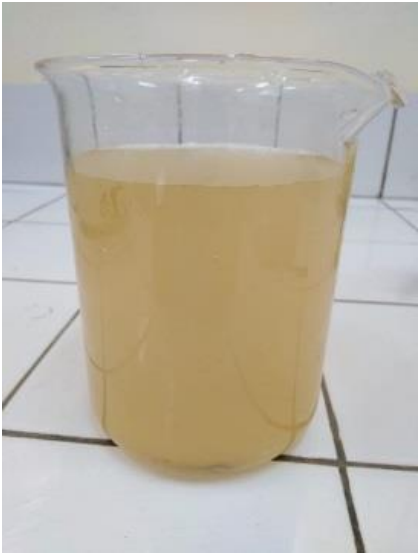

Before treatment
These results allow us to corroborate the performance of this treatment, which was applied with previously optimized parameters. These tests were performed to prove the effectiveness of our treatment.

The following Figure 9 show the appearance of the dam water before and after electrocoagulation.

Figure 9. Observation of our solution before and after treatment

\subsection{Fluorescence $X$}

The results of the chemical analysis of the main

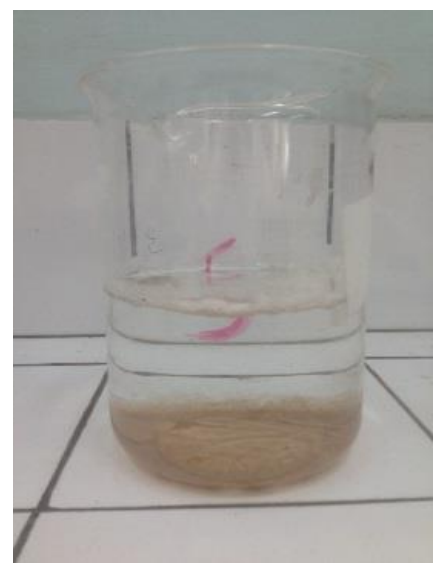

After treatment

Table 4. Elemental chemical composition of clay.

\begin{tabular}{|c|c|c|c|c|c|c|c|c|c|c|c|}
\hline Elements & $\mathrm{Al}_{2} \mathbf{O}_{3}$ & $\mathbf{F e}_{2} \mathbf{O}_{3}$ & $\mathbf{C a O}$ & $\mathbf{M g O}$ & $\mathbf{T i O}_{2}$ & $\mathbf{M n O}$ & $\mathbf{S i O}_{2}$ & $\mathbf{S O}_{3}$ & $\mathbf{C l}$ & $\mathbf{K}_{2} \mathbf{O}$ & $\mathbf{P}_{2} \mathbf{O}_{5}$ \\
\hline $\begin{array}{c}\text { \% } \\
\text { massique }\end{array}$ & 16,22 & 7,51 & 0,65 & 0,46 & 1,80 & 0,29 & 70,13 & 0,17 & 0,41 & 2,79 & 0,70 \\
\hline
\end{tabular}

Table 5. Elemental chemical composition of the sludge.

\begin{tabular}{|c|c|c|c|c|c|c|c|c|c|c|c|}
\hline Elements & $\mathrm{Al}_{2} \mathbf{O}_{3}$ & $\mathbf{F e}_{2} \mathbf{O}_{3}$ & $\mathbf{C a O}$ & $\mathbf{M g O}$ & $\mathbf{T i O}_{2}$ & $\mathbf{M n O}$ & $\mathrm{SiO}_{2}$ & $\mathbf{S O}_{3}$ & $\mathbf{C l}$ & $\mathbf{K}_{2} \mathrm{O}^{2}$ & $\mathbf{P}_{2} \mathrm{O}_{5}$ \\
\hline $\begin{array}{c}\boldsymbol{\%} \\
\text { massique }\end{array}$ & 57,90 & 3,15 & 2,25 & 7,03 & 0,60 & 0,18 & 19,41 & 5,53 & 2,70 & 1,05 & 0,74 \\
\hline
\end{tabular}

The elementary chemical analysis shows that the most abundant compounds in both samples are $\mathrm{SiO}_{2}$ and $\mathrm{Al}_{2} \mathrm{O}_{3}$, this indicates the presence of Kaolinite $\left(\mathrm{Al}_{2} \mathrm{Si}_{2} \mathrm{O}_{5}(\mathrm{OH})_{4}\right)$ and illite $\left[\left(\mathrm{K}, \mathrm{H}_{3} \mathrm{O}\right) \mathrm{Al}_{2} \mathrm{Si}_{3} \mathrm{AlO}_{10}(\mathrm{OH})_{2}\right]{ }^{27}$. The $\mathrm{SiO}_{2} / \mathrm{Al}_{2} \mathrm{O}_{3}$ mass ratio is 4.3 and 0.27 , respectively, for raw clay and sludge, indicating the presence of free quartz ${ }^{28}$ elements of the raw clay and sludge are illustrated in the following two Tables 4, 5, respectively: in the clay fraction. The low $\mathrm{CaO}$ content indicates a low quantity of calcium carbonate ${ }^{29}$.

\subsection{X-ray diffraction:}

The DRX diagrams for the solid phases (raw clay and electrocoagulation sludge) are shown in Figure 10. 


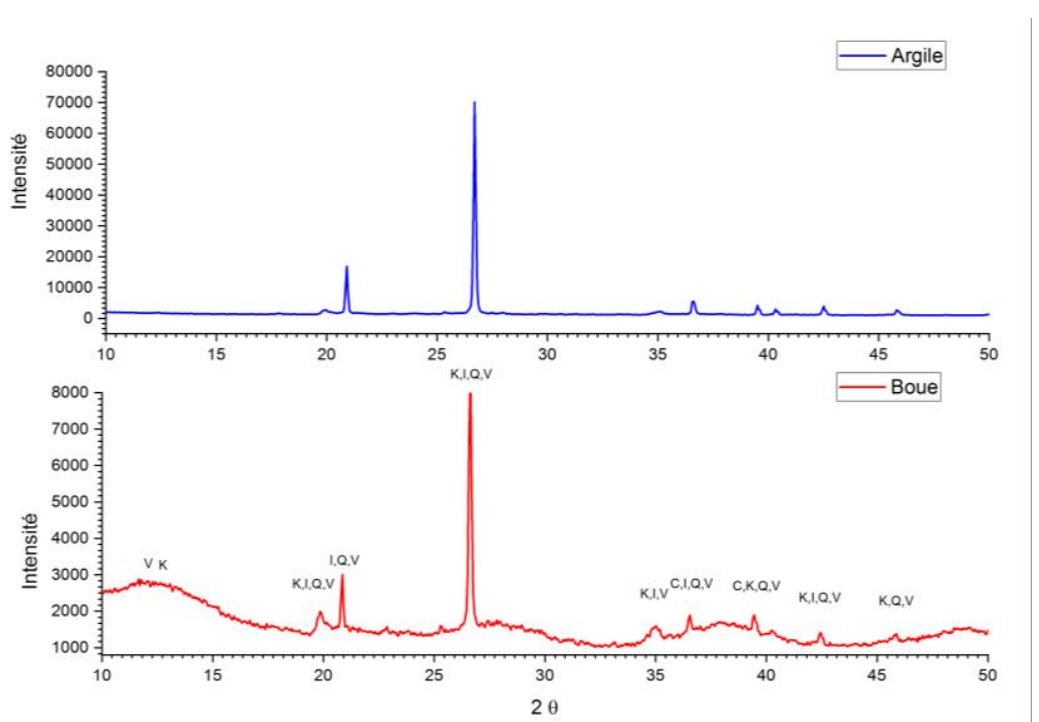

Figure 10. X-ray diffractogram of raw clay and sludge, with $\mathrm{K}=$ Kaolinite, $\mathrm{I}=\mathrm{Illite}, \mathrm{Q}=\mathrm{Quartz}, \mathrm{C}=\mathrm{Calcite}$, $\mathrm{V}=$ Vermiculite

From these diagrams, we can see that there are new peaks that appear in the second phase (Sludge). These are new structures that appear and others that disappear, probably as a result of a reaction between the two solids (clay and aluminum hydroxide).

The diffractograms also reveal the presence of clay minerals and crystalline phases, mainly in the form of tectosilicates (Quartz, feldspar...) ${ }^{30}$. Spectral analysis indicates that it is composed of Quartz $\left(\mathrm{SiO}_{2}\right)$, Calcite $\mathrm{Ca}\left(\mathrm{CO}_{3}\right)$, Kaolinite $\left(\mathrm{Al}_{2} \mathrm{Si}_{2} \mathrm{O}_{5}(\mathrm{OH})_{4}\right)$, Illite $\left[\left(\mathrm{K}, \mathrm{H}_{3} \mathrm{O}\right) \mathrm{Al}_{2} \mathrm{Si}_{3} \mathrm{AlO}_{10}(\mathrm{OH})_{2}\right]$ and vermiculite $\left[(\mathrm{Mg}, \mathrm{Al})_{3}(\mathrm{Si}, \mathrm{Al})_{4} \mathrm{O}_{10}(\mathrm{OH})_{2}, 4 \mathrm{H}_{2} \mathrm{O}\right]$. It mainly reveals the presence of an intense peak, which corresponds to a mixture of Quartz, Illite, Kaolinite, and Vermiculite. The clay fraction of our material is constituted of Quartz as a major impurity in our sample, and this confirms the results of the X-ray fluorescence, which shows high proportions of $\mathrm{SiO}_{2}$ (Quartz).

\section{Conclusion}

We have shown that the efficiency of electrocoagulation treatment depends on each of these two parameters: volume and stirring speed. For a volume of 1 liter of synthetic solution, the turbidity removal efficiency reaches $90 \%$ for a rotation speed of $20 \mathrm{rpm}$. This efficiency decreases to $17 \%$ at a rate of $60 \mathrm{rpm}$. The stirring power by unit volume is high. This is confirmed by the $60 \mathrm{rpm}$ test on a 5-liter volume, which improved the efficiency, reaching $86 \%$ (compared to $17 \%$ for 1 liter).

The application of these optimized parameters to dam water confirmed the efficacy of the process. The turbidity removal efficiency obtained is $86 \%$ and $89 \%$ successively for 1 liter and 5 liters.

Sludge characterization using X-ray diffraction analysis shows the formation of new structures in the clay mixture and aluminum hydroxide flocs based on an interaction between clay and aluminum hydroxide flocs.

The results obtained in this work are compelling and show that the electrocoagulation system is a very interesting process for the elimination of turbidity.

The results obtained in this work are compelling and show that the electrocoagulation system is an exciting process for the elimination of turbidity. To make good exploitation of these results the continuation of our study will be the realization of this system for the treatment of wastewater and after an application to full scale.

\section{References}

1- B. Lekhlif, F. Eddaqaq, A. Dani, K. Digua, B. Bejjany, E. Lakhdar, Z. AitYacine, H. Hanine, Role of clay in the treatment of surface water by Electrocoagulation, Physical and Chemical News, 2013, 69, 52-60.

2- E. Butler, Y. T. Hung, R. Y. L. Yeh, M. S. A. Ahmad, Electrocoagulation in Wastewater Treatment, Water, 2011, 3, 495-525.

3- L. K. Dubrawski, M. Mohseni, In-situ identification of iron electrocoagulation speciation and application for naturalorganicmatter (NOM) removal, water research, 2013, 47, 5371-5380.

4- F. Asgharyan, M. K. Nikou, B. Anvaripour, I. Danaee, The Effect of Different Electrodes on Humic Acid Removal by Electrocoagulation, Iranian Journal of Oil \& Gas Science and Technology, 2018, 7 (2), 52-63.

5- M. Bennajah, Traitement des rejets industriels liquide par électrocoagulation/électroflotation en réacteur airlift, l'institut national polytechnique de toulouse, France, 2007.

6- S. Chellam, M. A. Sari, Aluminum electrocoagulation as pretreatment during microfiltrationof surface water containing NOM: 
A review of fouling, NOM, DBP, and virus control, Journal of Hazardous Materials, 2016, 304, 490-501.

7- M. Han, J. Song, A. Kwon, preliminary investigation of electrocoagulation as a substitute for chemical coagulation, Water Science and Technology, 2002, 2, 73-76.

8- M. Kobyaa, U. Gebologlu, F. Ulu, S. Oncel, E. Demirbas, removal of arsenic from drinking water by the electrocoagulation using fe and al electrodes, Electrochimica Acta, 2011, 56, 5060-5070.

9- A. S. Escobara, A. P. Mateusa, A. L. Vasquezb, Electrocoagulation-photocatalyticprocess for the treatment of lithographic wastewater. Optimization using response surface methodology (RSM) and kineticstudy, Catalysis today, 2016, 266, 120-125.

10-G. Chen, Electrochemical technologie in wastewater treatement, Separation and Purification Technology, 2004, 38, 11-41.

11-P. Aswathy, R. Gandhimathi, S. T. Ramesh, P. V. Nidheesh, Removal of organics from bilge water by batch electrocoagulation process, Separation and Purification Technology, 2016, 159, 108-115.

12-K. Ulucan, H. A. Kabuk, F. Ilhan, U. Kurt, Electrocoagulation process application in bilge water treatment using response surface methodology, Int. J. Electrochem. Sci., 2014, 9, 2316-2326.

13-F. Sher, K. Hanif, S. Z. Iqbal, M. Imran, Implications of advanced wastewater treatment: Electrocoagulation and electroflocculation of effluent discharged from a wastewater treatment plant, Journal of Water Process Engineering, 2020, 33, 101101.

14-T. R. Devlin, M. S. Kowalski, E. Pagaduan, X. Zhang, V. Wei, J. A. Oleszkiewicz, Electrocoagulation of wastewater using aluminum, iron, and magnesium electrodes, J. Hazard. Mater., 2019,368, 862-868.

15-M. Elazzouzi, K. Haboubi, M. S. Elyoubi, Electrocoagulation-flocculation as a low-cost process for pollutants removal from urban wastewater, 2017, 117, 614-626.

16-P. M. Bertsch, D. R. Parker, Aqueous polynuclear aluminum species, The Environmental Chemistry of Aluminum; ed. by G. Sposito; Lewis Publishers: London, 1995, 117-168.

17-S. Lu, R. J. Pugh, E. Forssberg, Interfacial separation of particles; ed.by D. Mobius, R. Miller; Elsevier, Amsterdam, 2005, 336.

18-F. Zidane, P. Drogui, B. Lekhlif, J. Bensaid, J. F. Blais, S. Belcadi, K. Kacemi. Decolourization of dye-containing effluent using mineral coagulants produced by electrocoagulation. J. Hazard. Mater, 2008, 155, 153-163.

19-Y. Y. Han, G. Yu, Q. Zhuo, S. Deng, J. Wu, P. Zhang, Efficient removal of perfluoroalkyl acids (PFAAs) from aqueous solution by electrocoagulation using iron electrode, Chemical Engineering Journal, 2016, 303, 384-390.

20-K. P. Y. Shak, T. Y. Wu, Coagulationflocculation treatment of high-strength agroindustrial wastewater using natural Cassia obtusifolia seed gum: Treatment efficiencies and flocs characterization, Chem. Eng. J., 2014, 256, 293-305.

21-B. Khaled, B. Wided, H. Béchir, A. Limam, L. Mouna, Z. Tlili, Investigation of electrocoagulation reactor design parameters effect on the removal of cadmium from synthetic and phosphate industrial wastewater, Arabian Journal of Chemistry, 2019, 12, 1848-1859.

22-M. Ali Zazouli, M. Taghavi, E. Bazraschan, Influence of solution chemistry on phenol removal from aqueous environments by electrocoagulation process using aluminum electrodes, J. Health scope, 2012, 66-70.

23-F. Janpoor, A. Torabian, V. Khatibikamal, Treatment of laundry waste-water by electrocoagulation, J Chem Technol Biotechnol., 2011, 86, 1113-1120.

24-M. A. García-Morales, J. C. González Juárez, S. Martínez-Gallegos, G. Roa-Morales, E. Peralta, E. M. de.Campo López, C. BarreraDíaz, V. M. Miranda, T. T. Blancas, Pretreatment of Real Wastewater from the Chocolate Manufacturing Industry through an Integrated Process of Electrocoagulation and Sand Filtration, International Journal of Photoenergy, 2018, 2018, 1-7.

25-F. Eddaqaq, B. Lekhlif, A. Dani, K. Digua, Suspended Solids and Organic Matter Elimination from Superficial Raw Waters by Electrocoagulation Process in an Airlift Reactor Internal Loop, Int. J. Appl. Chem., 2016, 3, 1-6.

26-B. Merzouk, K. Madani, A. Sekki, Using electrocoagulation-electroflotation technology to treat synthetic solution and textile wastewater, two case studies, Desalination, 2010, 250, 573-577.

27-A. Qlihaa, S. Dhimni, F. Melrhaka, N. Hajjaji, A. Srhiri, Caractérisation physico chimique d'une argile Marocaine, J. Mater. Environ. Sci., 2016, 7, 1741-1750.

28-M. El Halim, L. Daoud1, M. El Ouahabi , J. Amakrane, N. Fagel, Mineralogy and firing characteristics of clayey materials used for ceramic purposes from Sale region (Morocco), J. Mater. Environ. Sci., 2018, 9, 622-634.

29-H. Sadki, K. Ziat, M. Saidi, Adsorption d'un colorant cationique d'un milieu aqueux sur une argile locale activée, Mater. Environ. Sci., 2014, 5, 2060-2065.

30-D. I. Nistor, N. D. Miron, I. Siminiceanu, Préparation des argiles pontées d'origine roumaine avec des polycations d'aluminium et de fer, scientific study and research, 2006, 7 (3), 505-514. 